Article

\title{
Rare-Earth-Doped Calcium Carbonate Exposed to $X$-ray Irradiation to Induce Reactive Oxygen Species for Tumor Treatment
}

\author{
Chun-Chen Yang ${ }^{1}$, Wei-Yun Wang ${ }^{1}$, Feng-Huei Lin ${ }^{2,3, *}$ and Chun-Han Hou ${ }^{4, *}$ \\ 1 Department of Materials Science and Engineering, National Taiwan University, Taipei 10617, Taiwan; \\ d03527007@ntu.edu.tw (C.-C.Y.); smallcloud929@hotmail.com.tw (W.-Y.W.) \\ 2 Institute of Biomedical Engineering, National Taiwan University, Taipei 10617, Taiwan \\ 3 Institute of Biomedical Engineering and Nanomedicine, National Health Research Institutes, \\ Miaoli 35053, Taiwan \\ 4 Department of Orthopedic Surgery, National Taiwan University, Taipei 10617, Taiwan \\ * Correspondence: double@ntu.edu.tw (F.-H.L.); chhou@ntu.edu.tw (C.-H.H.); \\ Tel.: +886-2-27327474 (F.-H.L.); +886-2-23123456 (ext. 65274) (C.-H.H.); \\ Fax: +886-2-27327474 (F.-H.L.); +886-2-23971266 (C.-H.H.)
}

\begin{abstract}
Conventional photodynamic therapy (PDT) is limited by its penetration depth due to the photosensitizer and light source. In this study, we developed $\mathrm{X}$-ray induced photodynamic therapy that applied X-ray as the light source to activate Ce-doped $\mathrm{CaCO}_{3}\left(\mathrm{CaCO}_{3}: \mathrm{Ce}\right)$ to generate an intracellular reactive oxygen species (ROS) for killing cancer cells. The A549 cell line was used as the in vitro and in vivo model to evaluate the efficacy of X-ray-induced $\mathrm{CaCO}_{3}: \mathrm{Ce}$. The cell viability significantly decreased and cell cytotoxicity obviously increased with $\mathrm{CaCO}_{3}: \mathrm{Ce}$ exposure under $\mathrm{X}$-ray irradiation, which is less harmful than radiotherapy in tumor treatment. $\mathrm{CaCO}_{3}:$ Ce produced significant $\mathrm{ROS}$ under $\mathrm{X}$-ray irradiation and promoted $\mathrm{A} 549$ cancer cell death. $\mathrm{CaCO}_{3}: \mathrm{Ce}$ can enhance the efficacy of X-ray induced PDT, and tumor growth was inhibited in vivo. The blood analysis and hematoxylin and eosin stain (H\&E) stain fully supported the safety of the treatment. The mechanisms underlying $\mathrm{ROS}$ and $\mathrm{CO}_{2}$ generation by $\mathrm{CaCO}_{3}$ :Ce activated by $\mathrm{X}$-ray irradiation to induce cell toxicity, thereby inhibiting tumor growth, is discussed. These findings and advances are of great importance in providing a novel therapeutic approach as an alternative tumor treatment.
\end{abstract}

Keywords: calcium carbonate; cerium; X-ray; alternative tumor treatment

\section{Introduction}

Photodynamic therapy (PDT), a common clinical treatment for tumors, uses light of specific wavelengths to activate photosensitizers (PS) to destroy or damage cells by the generation of reactive oxygen species (ROS) [1-3]. The excited PS can generate cytotoxic ROS, such as peroxides $\left(\cdot \mathrm{O}_{2}{ }^{2-}\right)$, superoxide ions $\left(\cdot \mathrm{O}_{2}{ }^{-}\right)$, hydroxyl radicals $(\cdot \mathrm{OH})$, and singlet oxygen $\left({ }^{1} \mathrm{O}_{2}\right)$ through type I and type II reactions, which mediate cell injury by peroxidising lipids or inactivating proteins leading to necrosis or apoptosis [4-6]. The oxidative power of a vast selection of photo-catalysts has been assessed and relevant operating parameters for the photo-degradation of methylene blue (MB) have been also investigated in a previous study [7].

Most clinical applications use light in the wavelength range of $630-800 \mathrm{~nm}$ to achieve the deepest tissue penetration, and several clinical photosensitizers available have significant absorption bands in this region [8]. However, the effective depth of treatment is typically less than $1 \mathrm{~cm}$, so that optimal light delivery to deep-seated or larger tumors or alternative nanoparticle strategies may be required $[9,10]$. 
Ionizing radiation, such as $\mathrm{X}$-rays or gamma rays, could be alternative light sources that enable deeper penetration $(8-14 \mathrm{~cm})$ in tissues with optimized sensitizers [11,12]. X-rays may interact with molecules to generate free radicals and ROS, which can damage DNA or cellular organelles [13-15]. Therefore, X-rays could be used as alternative light sources to achieve a deeper penetration depth and are less dangerous and hazardous than gamma rays [14].

Calcium carbonate $\left(\mathrm{CaCO}_{3}\right)$ has been used in drug delivery systems because of its great biocompatibility, low toxicity, easy production and slow biodegradability [16-18]. Principally, $\mathrm{CaCO}_{3}$ has three crystalline phases, namely calcite, vaterite and aragonite. Aragonite has an orthorhombic structure, usually found as needle-like particles, while calcite has a rhombohedral structure, often shaped as cubes [19]. Vaterite has a hexagonal structure that usually results in spherulitic particles and is rarely found in nature as it easily and irreversibly transforms into a more thermodynamically stable phase when in contact with water. Cerium (atomic number $=58$ ) is a non-toxic rare-earth element and has previously been proven to enhance photochemical reactions owing to its strong catalytic potential and light response extension $[20,21]$. It can also suppress the recombination of electron-hole pairs and extend their lifetime. In addition, cerium has a larger X-ray photon interaction cross-section than that of biological tissue constituents, which leads to intense X-ray interaction with host materials and consecutive ROS generation [22]. The entire process is illustrated in Figure 1.

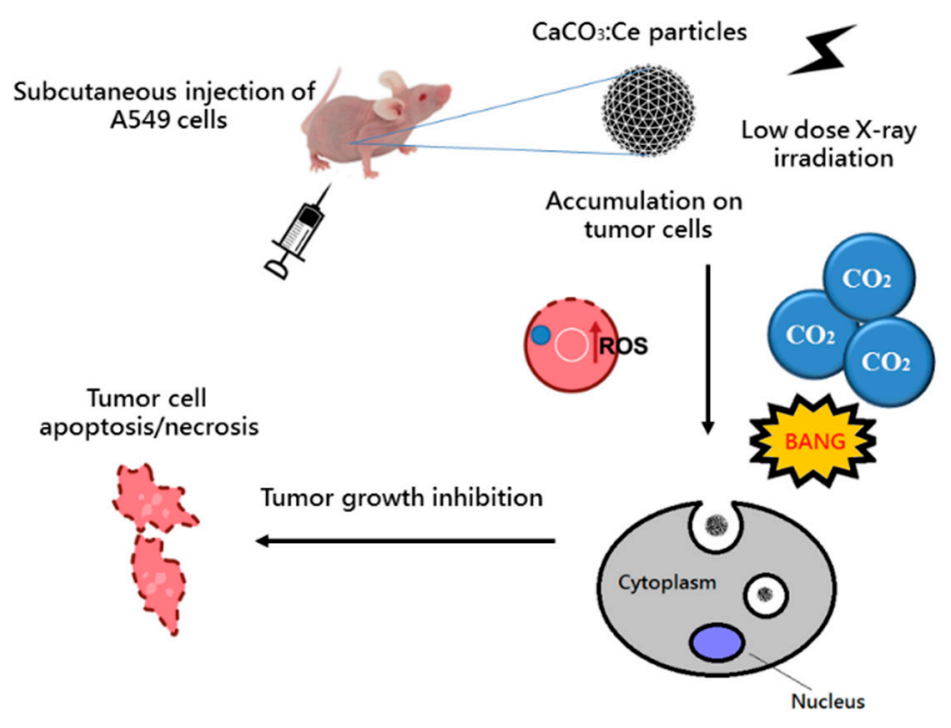

Figure 1. The mechanism of $\mathrm{CaCO}_{3}: \mathrm{Ce}$ activated by X-ray to generate $\mathrm{ROS}$ and $\mathrm{CO}_{2}$ for tumor growth inhibition.

The specific aim of this study was to synthesize $\mathrm{CaCO}_{3}$ :Ce phosphor that can be activated by $\mathrm{X}$-ray for photodynamic therapy, which can be used as an adjuvant therapy for cancer and lower the radiation dose.

X-ray diffraction (XRD), field-emission scanning electron microscopy (FESEM), and energy dispersive X-ray spectroscopy (EDX) were performed for crystal structure identification, surface morphology observation, and composition analysis, respectively. The degradation of methylene blue (MB) was evaluated to examine the generation of ROS. The adenocarcinoma human alveolar basal epithelial cell line (A549) was used for in vitro and in vivo studies to evaluate the effect of the synthesized $\mathrm{CaCO}_{3}: \mathrm{Ce}$ in X-ray-induced PDT. The in vitro testing of the synthesized $\mathrm{CaCO}_{3}: \mathrm{Ce}$ in $X$-ray-induced PDT was analyzed by lactate dehydrogenase (LDH) assay and then further assessed by live/dead staining. Tumor-induced BALB/c nude mice were used to check the efficacy and efficiency of the $\mathrm{CaCO}_{3}: \mathrm{Ce}$ as the photosensitizer in in vivo PDT treatment. A549 cells were injected into mouse thighs subcutaneously, to develop tumor lesions for use as an animal model. The tumor size was measured to examine the therapeutic result of the $\mathrm{CaCO}_{3}: \mathrm{Ce}$ in X-ray-induced PDT. The blood/serum 
analysis and hematoxylin and eosin stain (H\&E) examination were used for safety assessment of the mice. The results and findings in the study were collected and further analyzed to prove that the developed $\mathrm{CaCO}_{3}$ :Ce could be the most promising photosensitizer in X-ray-induced PDT for clinical use.

\section{Results}

The XRD pattern of $\mathrm{CaCO}_{3}$ :Ce particles is presented in Figure 2. The indexed peaks correspond to the hexagonal vaterite (JCPDS No. 72-0506), which are positioned at $2 \theta$ values of $21.1^{\circ}, 25.0^{\circ}$, $27.1^{\circ}, 32.8^{\circ}, 42.7^{\circ}, 43.9^{\circ}, 49.0^{\circ}, 50.2^{\circ}$ and $55.7^{\circ}$, corresponding to (101), (004), (112), (200), (105), and (211), respectively.

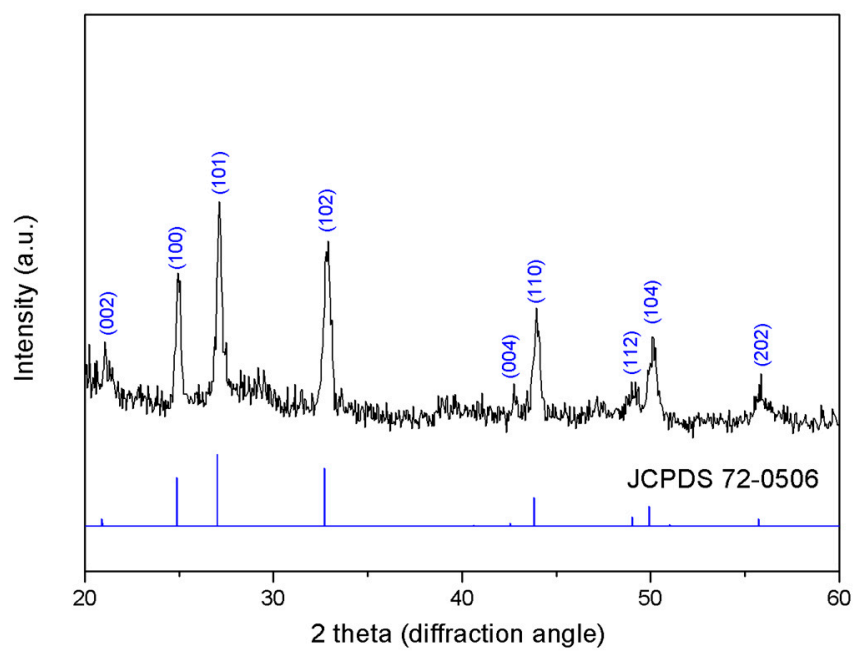

Figure 2. X-ray powder diffraction pattern of $\mathrm{CaCO}_{3}$ : $\mathrm{Ce}$ by $\mathrm{Cu} \mathrm{K} \alpha$ radiation $(\lambda=1.5406 \AA)$ in $2 \theta$ ranging from $20^{\circ}$ to $60^{\circ}$.

Figure 3 shows the SEM images of the $\mathrm{CaCO}_{3}$ :Ce particles. It is evident that the spherical particles have a size of approximately 1-3 $\mu \mathrm{m}$ with uniform distribution from the low magnification image. From the high magnification view, the isolated micro-pores were found to have an average size of about $500 \mathrm{~nm}$. The results of Brunauer-Emmett-Teller (BET) test was shown in Table S1.
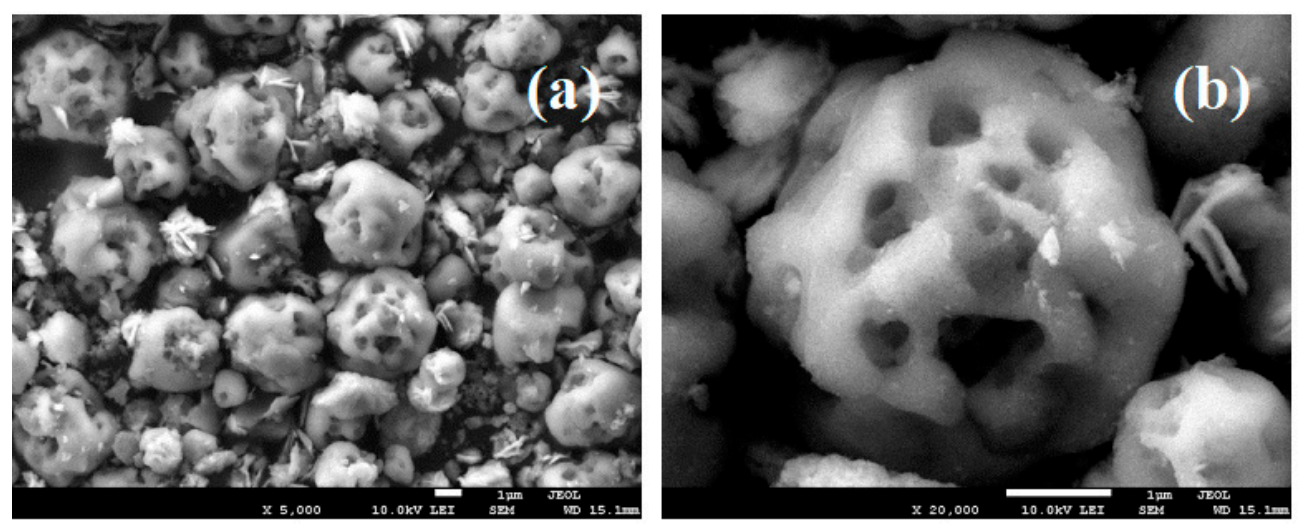

Figure 3. SEM images of $\mathrm{CaCO}_{3}$ :Ce particles at the (a) low magnification; (b) high magnification.

Figure 4 shows the chemical composition analysis of $\mathrm{CaCO}_{3}$ :Ce by EDX, one of the accessories of the SEM. Ca, C, O, and Ce elements were detected. There was no trace of any other elements or contaminants within the detection limit of the EDX. The atomic ratio of cerium to calcium was 1:22.5. 


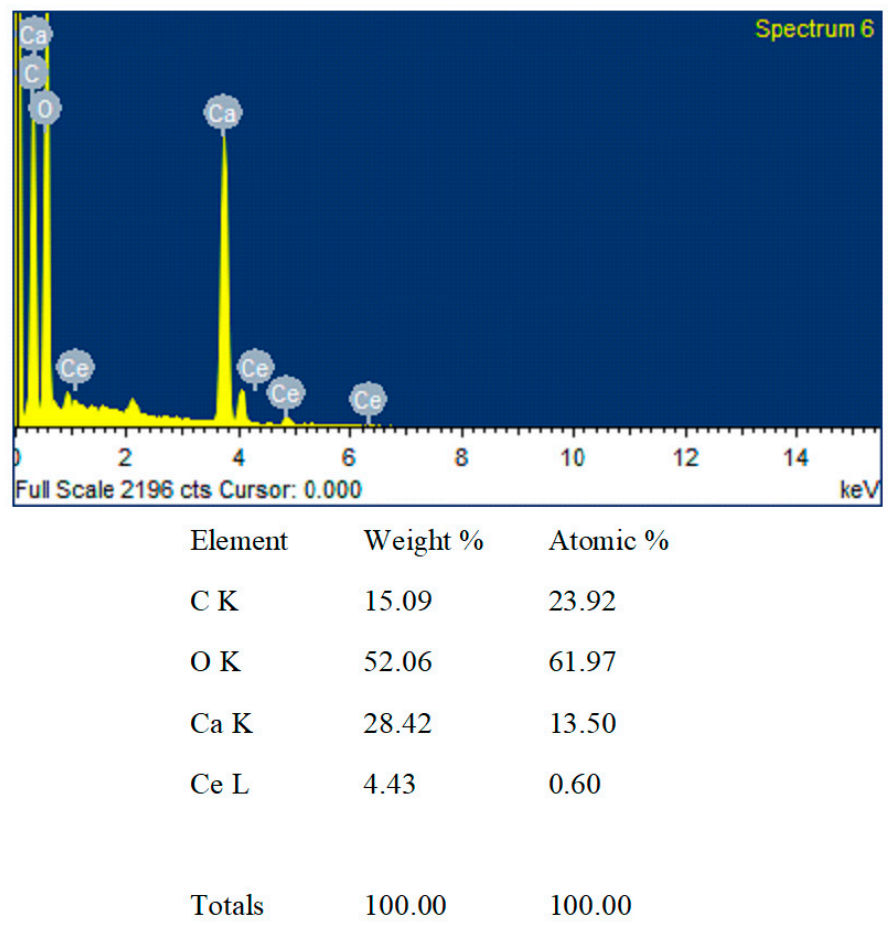

Figure 4. Spectra and chemical composition chart of $\mathrm{CaCO}_{3}: \mathrm{Ce}$ particles.

Figure 5 shows that there is no difference between $10 \mathrm{ppm} \mathrm{MB}$ solution without and with X-ray irradiation. When $10 \mathrm{mg} \mathrm{CaCO}$ :Ce particles were added to the $\mathrm{MB}$ solution and exposed to $\mathrm{X}$-rays, MB was degraded by up to $14.37 \%$ compared to without $\mathrm{X}$-ray exposure. This result indicated the significant generation of $\mathrm{ROS}$ from $\mathrm{CaCO}_{3}$ :Ce when exposed to X-ray irradiation.

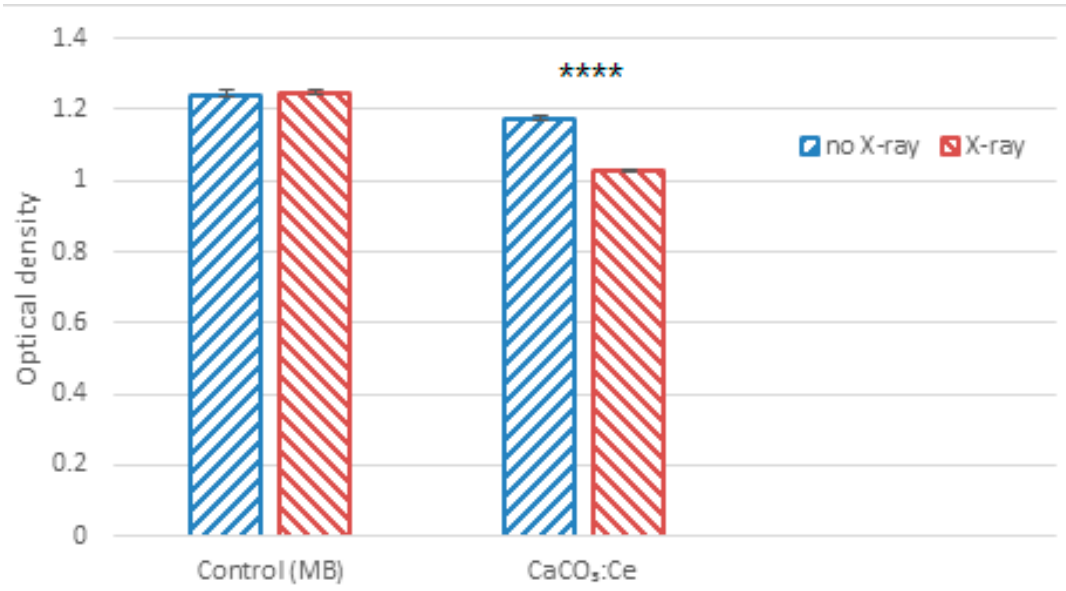

Figure 5. The generation of $\mathrm{ROS}$ of $\mathrm{CaCO}_{3}$ :Ce particles under X-ray irradiation determined by the degradation of methylene blue ( $t$-test, mean $\pm S D, n=6,{ }^{* * * *}: p$-value $\left.<0.0001\right)$.

The in vitro PDT effects of $\mathrm{CaCO}_{3}$ :Ce activated by X-ray irradiation were evaluated using $\mathrm{LDH}$ assay with A549 lung cancer cells (Figure 6). At day 3, the death rate of A549 cells in XCC5 was $27.65 \pm 0.79 \%$. Cytotoxicity in CC10 at day 3 was at acceptable levels of $26.35 \pm 0.99 \%$. In contrast, cytotoxicity in the XCC10 group was $34.36 \pm 1.77 \%$, which indicated the cellular death caused by $\mathrm{CaCO}_{3}:$ Ce after exposure to X-ray irradiation. 


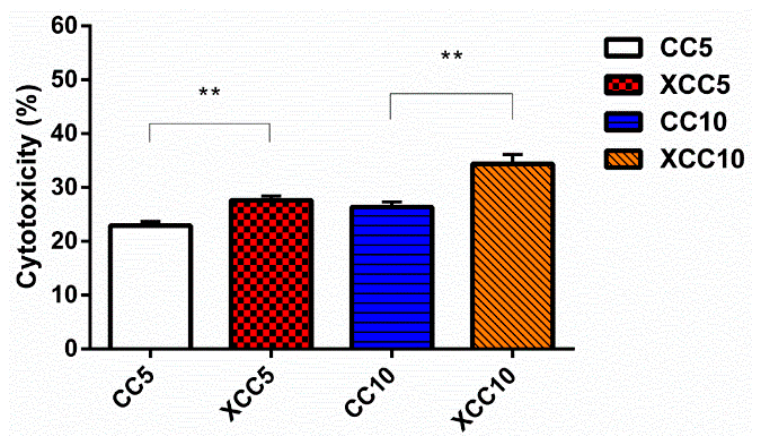

Figure 6. Cell cytotoxicity induced by $\mathrm{CaCO}_{3}$ :Ce under X-ray irradiation ( $t$-test, mean $\pm \mathrm{SD}, n=6$, $* *$ :value $<0.01)$.

The results of live/dead assay are shown in Figure 7 to evaluate cell viability of $\mathrm{CaCO}_{3}: \mathrm{Ce}$ under X-ray irradiation. At day 3, a large number of live A549 cells (green fluorescence) were found in the control group (Figure 7a). Both the $\mathrm{X}$-ray treated group (Figure $7 \mathrm{~b}$ ) and $\mathrm{CaCO}_{3}$ :Ce group (Figure $7 \mathrm{c}$ ) show very few dead cells (red fluorescence), which was in agreement with the biocompatibility results. In Figure $7 \mathrm{~d}$ a large number of dead cells following $\mathrm{CaCO}_{3}$ :Ce after being activated by $\mathrm{X}$-ray irradiation can be seen, indicating the decrease in cell viability and cellular death.
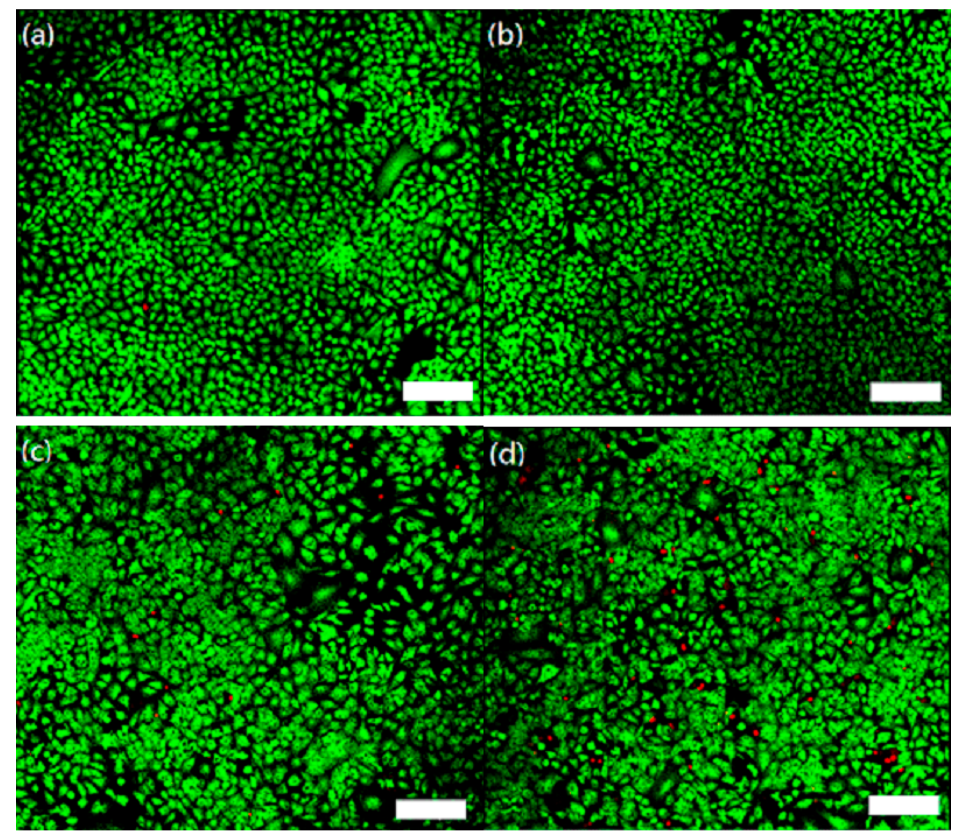

Figure 7. The PDT efficacy of $\mathrm{CaCO}_{3}$ :Ce exposed to X-ray irradiation, evaluated by live/dead staining of (a) control group; (b) X-ray-treated group; (c) $\mathrm{CaCO}_{3}: C e$ group; and (d) $\mathrm{PDT}_{-\mathrm{CaCO}}$ :Ce group, where living cells produced green fluorescence and dead cells showed red fluorescence (scale bars: $200 \mu \mathrm{m})$.

After the effect of $\mathrm{CaCO}_{3}$ :Ce under X-ray irradiation was proven to kill A549 cancer cells in vitro, an in vivo study was carried out to prove the PDT effect as well (Figure 8). Due to the consideration of the cell killing effect and to reduce the use of animals, we chose $\mathrm{CaCO}_{3}: \mathrm{Ce}$ under $X$-ray irradiation, indicated as $\mathrm{PDT}-\mathrm{CaCO}_{3}: \mathrm{Ce}$, as the main experimental group. The anti-tumor efficacy of the PDT-CaCO $3:$ Ce group was evaluated by the change in tumor size in male BALB/c nude mice. Figure 8a shows that the tumor volume of the control group at day 14 had increased up to $140 \%$ compared to the initial volume. In contrast, on day 14 , the tumor volume of the $\mathrm{PDT}-\mathrm{CaCO}_{3}: \mathrm{Ce}_{\text {group }}$ sharply decreased to nearly $15 \%$ of the initial volume. The results indicated that $\mathrm{CaCO}_{3}: \mathrm{Ce}$ could be a promising photosensitizer activated by $\mathrm{X}$-ray to great anti-tumor effect. 

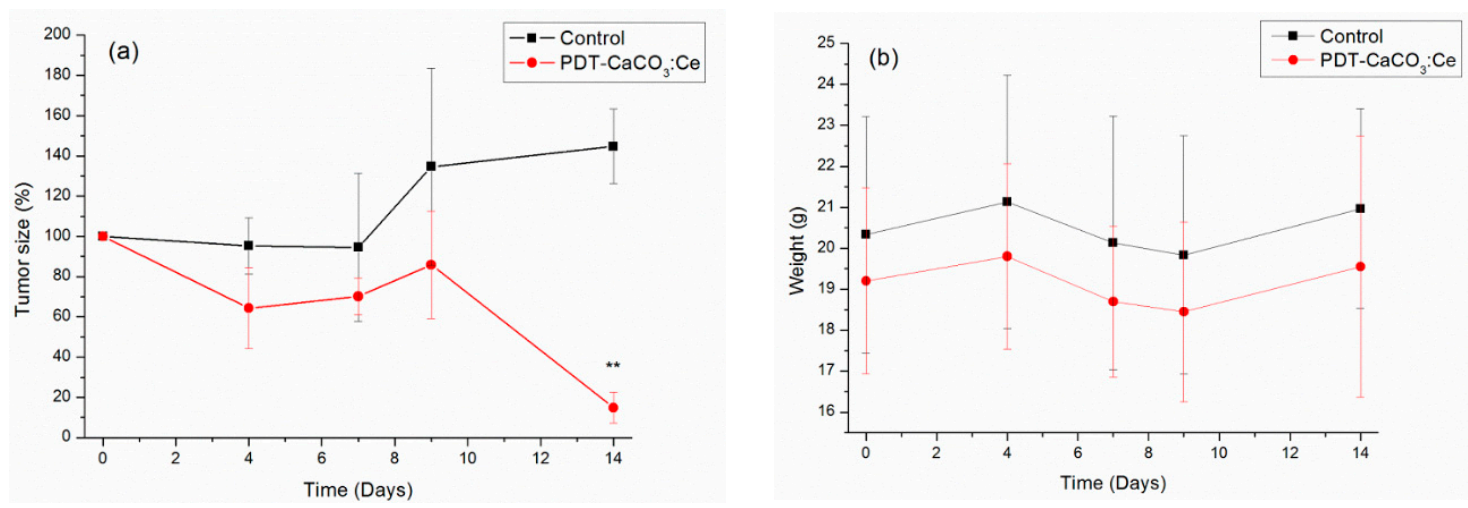

Figure 8. The tumor size (a) and body weight (b) in BALB/c nude mice injected with $\mathrm{CaCO}_{3}: \mathrm{Ce}$ and subjected to X-ray irradiation $\left(t\right.$-test, mean $\pm \mathrm{SD}, n=4,{ }^{* *}: p$-value $<0.01$ ).

The safety efficacy of PDT-CaCO 3 :Ce was evaluated by whole blood/serum analysis and H\&E examination. From the blood/serum biochemical analysis (Table 1), it was found that all parameters of the PDT- $\mathrm{CaCO}_{3}: \mathrm{Ce}$ group complied with the standard and were in the range of the standards of blood biochemical analysis (Table 2). The heart, lung, liver, kidney, and spleen were harvested from the mice to determine the toxicity that could arise from the effect of $\mathrm{CaCO}_{3}: \mathrm{Ce}$ after X-ray irradiation.

Table 1. Bio-chemical analysis of blood samples from $\mathrm{PDT}-\mathrm{CaCO} \mathrm{C}_{3}$ :Ce group.

\begin{tabular}{ccc}
\hline Analysis & Standard & PDT-CaCO $_{3}$ :Ce Group \\
\hline $\mathrm{RBC}(\mathrm{M} / \mu \mathrm{L})$ & $7.42-9.86$ & 9.46 \\
$\mathrm{Hb}(\mathrm{g} / \mathrm{dL})$ & $12.70-18.40$ & 15.00 \\
$\mathrm{HCT}(\%)$ & $35.44-47.16$ & 46.40 \\
$\mathrm{MCV}(\mathrm{fL})$ & $45.74-49.86$ & 49.00 \\
$\mathrm{MCH}(\mathrm{pg})$ & $13.30-16.50$ & 15.90 \\
$\mathrm{MCHC}(\mathrm{g} / \mathrm{dL})$ & $29.09-36.29$ & 32.30 \\
$\mathrm{WBC}(\mathrm{K} / \mu \mathrm{L})$ & $2.19-3.63$ & 3.11 \\
$\mathrm{LYMPH}(\mathrm{K} / \mu \mathrm{L})$ & $0.15-0.87$ & 1.12 \\
$\mathrm{MONO}(\mathrm{K} / \mu \mathrm{L})$ & $0.09-0.53$ & 0.17 \\
\hline
\end{tabular}

Table 2. Bio-chemical analysis of the blood/serum samples from PDT-CaCO $3:$ Ce group.

\begin{tabular}{ccc}
\hline Analysis & Standard & PDT-CaCO $_{3}:$ Ce Group $^{-}$ \\
\hline BUN (mg/dL) & $18.00-45.00$ & 31.13 \\
CREA (mg/dL) & $0.08-0.13$ & 0.10 \\
ALT (U/L) & $27.00-78.00$ & 63.00 \\
ALB (g/L) & $26.57-35.43$ & 29.70 \\
Ca (mmol/L) & $2.18-2.44$ & 2.46 \\
IP (mg/dL) & $5.53-10.19$ & 9.71 \\
\hline
\end{tabular}

Figure 9 shows no significant difference between the experimental group and control group, including no observable signs of side effects on normal tissues from H\&E staining. 


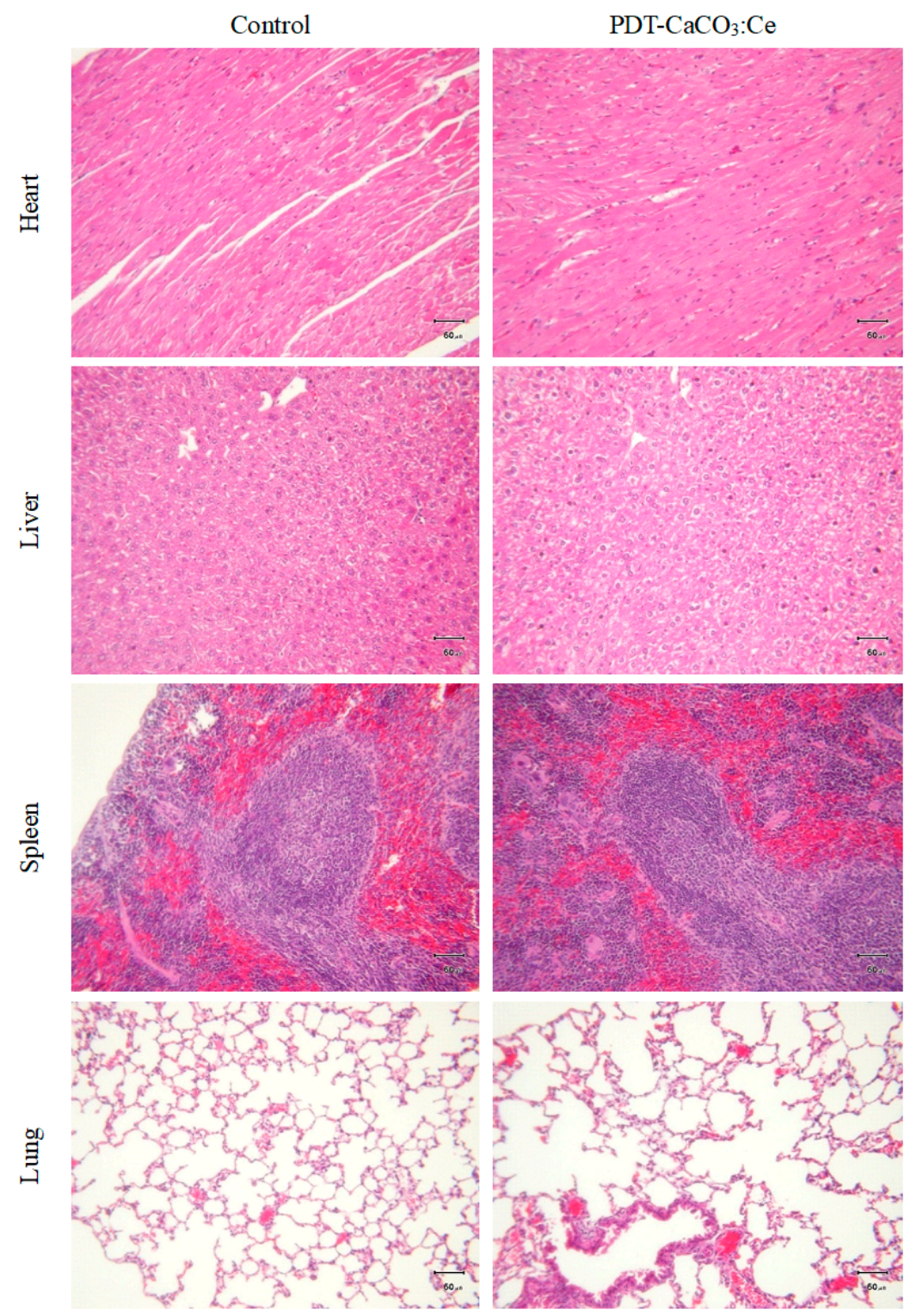

Figure 9. H\&E-stained slices of major organs harvested from scarified BALB/c nude mice at the end of the animal study and examined under optical microscope (scale bar: $50 \mu \mathrm{m}$ ).

\section{Discussion}

The option of using photosensitizers and light sources to improve the shallow tissue penetration depth has been garnering significant interest as a key element of an alternative therapeutic modality. The size, shape and structure of a material, which relate to toxicity, are viewed as an important determination for use as a photosensitizer, so it is necessary to characterize materials before cell viability and cell cytotoxicity tests [23-25].

$\mathrm{CaCO}_{3}$ :Ce was successfully synthesized using the co-precipitation method and confirmed by crystalline phase identification, as shown in Figure 2. The $\mathrm{CaCO}_{3}: \mathrm{Ce}$ particle was spherical with a diameter of 1-3 $\mu \mathrm{m}$. The surface of the particles was very rough and consisted of a large number of pores and channels (Figure 3). Large particles are most likely to be engulfed via micropinocytosis [26]. The spherical and rough particles will have a larger surface area, which may cause higher reactivity with nearby particles, resulting in possibly harmful effects, such as oxidative stress, ROS generation, and mitochondrial perturbation $[27,28]$. The biological identity that could influence ist interactions with the cells was further observed in the cell viability and cell cytotoxicity tests. X-ray was used 
as the alternative light source to activate the photosensitizer in this study. The results indicated that the degradation of $\mathrm{MB}$ in the absence of $\mathrm{X}$-ray would greatly extend the range of applications for $\mathrm{CaCO}_{3}$-based degradation processes, which is evident that the oxidative behavior is due to the generation of ROS at the catalyst surface (Figure 5). The increase in ROS caused by exposure to X-ray irradiation may be attributed to the oxygen enhancement of radiolysis by ionizing radiation $[29,30]$. Cerium provides a larger photon interaction cross-section to absorb high-energy X-ray irradiation, which induces the excitation and ionization of water molecules, leading to the overproduction of ROS [22,31]. It is suggested that when the antioxidant defenses are overwhelmed, the overproduction of ROS in cancer cells, which leads to oxidative damage to the proteins, DNA, and lipids in mitochondria may cause mitochondrial dysfunction [32,33]. Briefly, when the increase in ROS reaches the toxic threshold, cell death will be triggered, as can be seen in Figure 6. Different $\mathrm{pH}$ values existed in the microenvironment of the tumor tissues ( $\mathrm{pH}$ 6.5-6.8), cell endosomes ( $\mathrm{pH}$ 5.5-6.5), lysosomes ( $\mathrm{pH}$ 4.5-5.5), blood stream and normal tissues ( $\mathrm{pH} 7.4$ ) [34,35]. $\mathrm{CaCO}_{3}$ itself is known to react with protons and dissolve to generate $\mathrm{CO}_{2}$ gas in an acidic environment, as described in Equations (1) to (4) [36].

$$
\begin{gathered}
\mathrm{CaCO}_{3(\mathrm{~s})} \rightarrow \mathrm{Ca}^{2+}+\mathrm{CO}_{3}{ }^{2-} \\
\mathrm{CO}_{3}{ }^{2-}+\mathrm{H}^{+} \rightarrow \mathrm{HCO}_{3}{ }^{-} \\
\mathrm{HCO}_{3}{ }^{-}+\mathrm{H}^{+} \rightarrow \mathrm{H}_{2} \mathrm{CO}_{3} \\
\mathrm{H}_{2} \mathrm{CO}_{3} \rightarrow \mathrm{H}_{2} \mathrm{O}+\mathrm{CO}_{2}
\end{gathered}
$$

Previous studies show that $\mathrm{CO}_{2}$ affects the expression of intracellular messengers that relate to cell death, such as PGC-1a, TFAM, the protein levels of cleavage products of caspase-3, caspase-9, and PARP [37]. $\mathrm{CO}_{2}$ also significantly inhibits tumor growth, tumor new blood vessel formation, and cancer cell invasion by affecting the expression of hypoxia-inducible factor 1-alpha (HIF-1a), vascular endothelial growth factor (VEGF), matrix metalloproteinase-2 (MMP-2), and matrix metalloproteinase-9 (MMP-9) $[37,38]$. The mechanism of this was that $\mathrm{CaCO}_{3}$ :Ce would be identified as a foreign body by cells, which stimulates a foreign body reaction associated with the activation of neutrophils (also known as polymorphonuclear leukocytes, PMNs). The activation of neutrophils promotes the assembly of nicotinamide adenine dinucleotide phosphate (NADPH) oxidase subunits at phagosome and/or plasma membranes [39]. NADPH oxidases are integral membrane proteins that transfer electrons from NADPH to oxygen across biological membranes, generating $\mathrm{O}_{2}{ }^{-}$and $\mathrm{H}_{2} \mathrm{O}_{2}$ [40]. In the endosome/lysosome, the $\mathrm{pH}$ value was as low as 3-4, which may cause $\mathrm{CaCO}_{3}$ to dissolve in the confined space and produce $\mathrm{CO}_{2}$, which has a bombing effect that further causes cell death. ROS also react with membranes and can oxidize membrane proteins, cholesterol and polyunsaturated lipids in a process called lipid peroxidation, resulting in cell death [41]. After $\mathrm{CaCO}_{3}:$ Ce excitation by $\mathrm{X}$-ray, causing oxidative damage and a decrease in cell viability that is related to either intracellular component leakage or Ce entrance into the damaged cells, and the direct attack of nuclei and other intracellular components (Figure 7). On the other hand, $\mathrm{CaCO}_{3}: \mathrm{Ce}$ could react in an acidic tumor environment to generate $\mathrm{CO}_{2}$. The small $\mathrm{CO}_{2}$ bubbles hiding in porous channels of $\mathrm{CaCO}_{3}$ : $\mathrm{Ce}$ would burst after exposure to $\mathrm{X}$-ray, resulting in inertial cavitation. These $\mathrm{CO}_{2}$ bubbles will instantly explode to destroy tumor tissues and vessels once exposed to X-ray, and consequently occlude the blood supply within the tumor, inducing cell necrosis. The observations of in vivo tumor size (Figure 8) indicated that $\mathrm{CaCO}_{3}: \mathrm{Ce}$ activated by $\mathrm{X}$-ray could be an effective method to cause evident cell death and inhibit tumor growth. $\mathrm{CaCO}_{3}: \mathrm{Ce}$ is also non-toxic without exposure to $\mathrm{X}$-ray. It possesses great biocompatibility, low toxicity, causing no side effects to normal tissues after treatment (Figure 8). $\mathrm{CaCO}_{3}: \mathrm{Ce}$ activated by $\mathrm{X}$-ray could be a promising approach for further adjunctive tumor treatment. 


\section{Materials and Methods}

\subsection{Preparation of $\mathrm{CaCO}_{3}: \mathrm{Ce}$}

Briefly, $0.53 \mathrm{~g}$ of sodium carbonate $\left(\mathrm{Na}_{2} \mathrm{CO}_{3}\right.$, Sigma-Aldrich, St. Louis, $\left.\mathrm{MO}, \mathrm{USA}\right)$ was dissolved in $50 \mathrm{~mL} \mathrm{ddH}_{2} \mathrm{O}$ to make $0.1 \mathrm{M} \mathrm{Na}_{2} \mathrm{CO}_{3}$ solution. Secondly, $40 \mathrm{~g} / \mathrm{L}$ of PVA (Sigma-Aldrich) and $0.618 \mathrm{~mL}$ Tween 80 (Sigma-Aldrich) were mixed with $\mathrm{Na}_{2} \mathrm{CO}_{3}$ solution, and then added into $50 \mathrm{~mL}$ ddH $\mathrm{H}_{2} \mathrm{O}$ as Solution A. After that, $1.18 \mathrm{~g}$ of calcium nitrate tetrahydrate $\left(\mathrm{Ca}\left(\mathrm{NO}_{3}\right)_{2} \cdot 4 \mathrm{H}_{2} \mathrm{O}\right.$, Sigma-Aldrich) was dissolved in $50 \mathrm{~mL}$ ddH ${ }_{2} \mathrm{O}$ to make $0.1 \mathrm{M} \mathrm{Ca}\left(\mathrm{NO}_{3}\right)_{2} \cdot 4 \mathrm{H}_{2} \mathrm{O}$ solution. Next, $0.217 \mathrm{~g}$ of Cerium(III) nitrate hexahydrate $\left(\mathrm{Ce}\left(\mathrm{NO}_{3}\right)_{3} \cdot 6 \mathrm{H}_{2} \mathrm{O}\right.$, Alfa, Ward Hill, MA, USA) was mixed with $\mathrm{Ca}\left(\mathrm{NO}_{3}\right)_{2} \cdot 4 \mathrm{H}_{2} \mathrm{O}$ solution,

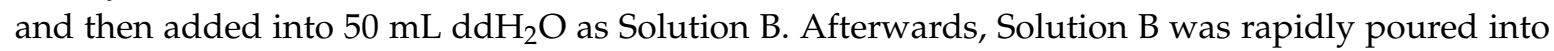
Solution $\mathrm{A}$ and stirred at room temperature for $1 \mathrm{~h}$ to obtain the mixture. The mixture was added drop wise to $100 \mathrm{~mL}$ hexane (Sigma-Aldrich), and then rinsed with ethanol. The sample was dried in an oven and calcined at $325^{\circ} \mathrm{C}$ for $2 \mathrm{~h}$.

\subsection{Material Characterization}

The crystalline phase of the synthesized $\mathrm{CaCO}_{3}: \mathrm{Ce}$ was determined by X-ray diffractometry (XRD; Philips, 1830/Mac, Amsterdam, The Netherlands) with CuK $\alpha$ radiation $(\lambda=0.15406 \mathrm{~nm})$ at $30 \mathrm{kV}$ and $15 \mathrm{~mA}$. The diffraction patterns were collected at a scanning speed of $2^{\circ} / \mathrm{min}$ from $20^{\circ}$ to $60^{\circ}$. The surface morphologies were observed with a field-emission scanning electron microscope (FESEM; JEOL, JSM-7600F, Akishima, Tokyo, Japan) at $10 \mathrm{kV}$ and $30 \mathrm{~mA}$. The chemical composition of the samples was analyzed with energy-dispersive X-ray spectroscopy (EDX; JEOL, JSM-7600F, Akishima, Tokyo, Japan).

\subsection{Degradation of $M B$ for ROS Detection}

In order to evaluate ROS production of the synthesized $\mathrm{CaCO}_{3}: \mathrm{Ce}$ under X-ray irradiation, the degradation of MB (Sigma-Aldrich) was analyzed by an enzyme-linked immunosorbent assay (ELISA, Thermo Scientific, Waltham, MA, USA) reader at an absorbance of $664 \mathrm{~nm}$. X-ray apparatus (POYE, PX-80M, New Taipei, Taiwan) at $80 \mathrm{kV}$ and $10 \mathrm{~mA}$ was used to generate X-ray at dose rate of $0.08 \mathrm{~Gy} / \mathrm{min}$ for $100 \mathrm{~s}$. Ten micrograms of $\mathrm{CaCO}_{3}:$ Ce was dispersed in $10 \mathrm{~mL}$ of aqueous solution of 10 ppm MB. Ten ppm MB with no particles was viewed as the control group.

\subsection{LDH assay: In Vitro Testing of Synthesized $\mathrm{CaCO}_{3}$ :Ce in PDT}

The effects of $\mathrm{CaCO}_{3}$ :Ce in PDT were analyzed by LDH assay (TaKaRa, Kusatsu, Shiga, Japan) to assess cell death rate, respectively. A549 cells were seeded on a 96-well plate at a density of $3 \times 10^{3}$ cells/well and then incubated at $37{ }^{\circ} \mathrm{C}$ in a $5 \% \mathrm{CO}_{2}$ atmosphere. One day after seeding, $100 \mu \mathrm{L}$ of $0.5 \mathrm{mg} / \mathrm{mL}$ and $1 \mathrm{mg} / \mathrm{mL}$ of synthesized particles were added to each well without X-ray irradiation, representing CC5 and CC10, respectively. The XCC5 and XCC10 stand for cells cultured with $\mathrm{CaCO}_{3}: \mathrm{Ce}$ in the concentration of $0.5 \mathrm{mg} / \mathrm{mL}$ and $1 \mathrm{mg} / \mathrm{mL}$ and subjected to X-ray radiation after incubating for $4 \mathrm{~h}$. The radiation parameters of the X-ray apparatus were described in Section 4.3. The cultured medium was collected for the LDH assay; $50 \mu \mathrm{L}$ of cultured medium was mixed and reacted with $50 \mu \mathrm{L}$ of $\mathrm{LDH}$ reagent for $30 \mathrm{~min}$ in the dark at room temperature. After the reaction, $50 \mu \mathrm{L}$ of stop solution was added to each well to stop the reaction, and then the cell death rate was evaluated by using a microplate reader at the absorbance of $490 \mathrm{~nm}$. F12K medium (Sigma-Aldrich) supplemented with 10\% Fetal Bovine Serum (FBS, Gibco, Waltham, MA, USA) and 1\% antibiotic-antimycotic (Gibco) was used for A549 cell culture. Each experiment was repeated 6 times.

\subsection{Live/Dead Staining: In Vitro Testing of Synthesized $\mathrm{CaCO}_{3}: \mathrm{Ce}$ in PDT}

The live/dead staining kit contains two components. A dye calcein AM (Thermo Fisher) that permeates the plasma membrane and when cleaved by intracellular esterases fluoresces green and 
can be used to identify live cells. The second dye, ethidium homodimer-1 (Thermo Fisher), exhibits red fluorescence when intercalated into the DNA of dead or damaged cells. A549 cells (BCRC) were seeded in a $3.5 \mathrm{~cm}$ culture dish (Thermo Fisher) at a density of $8.5 \times 10^{4}$ cells/dish and cultured for one day. The synthesized $\mathrm{CaCO}_{3}: \mathrm{Ce}(1 \mathrm{mg} / \mathrm{mL})$ in $2 \mathrm{~mL}$ of medium was added to each culture dish. After a $4 \mathrm{~h}$ reaction time, cells were irradiated with X-ray generated at $80 \mathrm{kV}$ and $10 \mathrm{~mA}$ at a dose rate of $0.08 \mathrm{~Gy} / \mathrm{min}$ for $100 \mathrm{~s}$. All dishes were incubated at $37^{\circ} \mathrm{C}$ in a $5 \% \mathrm{CO}_{2}$ atmosphere for one day. In the following two days, $1 \mathrm{~mL}$ of live/dead reagent prepared with phosphate-buffered saline (PBS, Thermo Fisher) was added into each dish and kept in the dark for $30 \mathrm{~min}$, and then observed with a confocal microscope.

\subsection{Tumor Observation: In Vivo Evaluation of Synthesized $\mathrm{CaCO}_{3}: \mathrm{Ce}$ in PDT}

A549 cells at a density of $10^{6}$ cells $/ 100 \mu \mathrm{L}$ suspended in PBS were subcutaneously injected into the thighs of seven-week-old male BALB/c nude mice, which were maintained in cages by normal feeding for 2 weeks until tumors grew to a volume of $25 \mathrm{~mm}^{3}$. The tumor volume was calculated using a Vernier caliper with the following formula: $v=0.5 a b^{2}$ (where $a$ is the long diameter of the tumor, $b$ is the short diameter of the tumor, and $v$ is volume). The mice were divided into two groups: (1) the control group was injected with only PBS at day 0 and day 7 without X-ray irradiation; and (2) the experimental group, abbreviated as PDT- $\mathrm{CaCO}_{3}: \mathrm{Ce}$, had an intratumoral injection of $\mathrm{CaCO}_{3}: \mathrm{Ce}$ particles at day 0 and day 7, and were exposed to X-ray irradiation at day 0, day 4, day 7 and day 9 . The whole experiment period from tumor growth until mice being sacrificed lasts for 4 weeks.

\subsection{Blood/Serum Analysis and Histological Examination: In Vivo Safety Testing of Synthesized $\mathrm{CaCO}_{3}: \mathrm{Ce}$ in PDT}

After all the mice were sacrificed, the whole blood, serum sample and internal organs were harvested for later analysis and examination as follows. Major organs were harvested and fixed with $10 \%$ formaldehyde. Fixed tissues were embedded in paraffin, sectioned into slices with a thickness of $5 \mu \mathrm{m}$, and stained with hematoxylin and eosin (H\&E) for histological examination. Whole blood was collected using $23 \mathrm{G}$ needles through cardiac puncture without thoracotomy, sampled into a tube with 7.5\% Ethylenediaminetetraacetic acid (EDTA) solution, and sent to the Animal Center of National Taiwan University for further analysis. Blood/serum biochemical analysis includes renal function testing, liver function testing, and electrolyte examination. Blood urine nitrogen (BUN) and creatinine (CREA) were used for renal function examination. Alanine aminotransferase (ALT), aspartate aminotransferase (AST), and albumin (ALB) are used for evaluation of liver function. Calcium (Ca) and inorganic phosphate (IP) were measured as an assessment of electrolytes. Blood biochemical analysis comprised blood routine and white blood cell classification. All of the animal experiments were executed according to the principles of the 3Rs-reduction, refinement, and replacement of animal use in research—supervised by the Animal Center of National Taiwan University for Animal Welfare.

\subsection{Statistical Analysis}

All of the data were collected and expressed as mean \pm standard deviation (SD) for the control and experimental groups. Statistical analysis was performed in GraphPad Prism 6 and analyzed by $t$-test in this study. The $p$ value $<0.05$ was considered statistically significant.

\section{Conclusions}

We developed $\mathrm{CaCO}_{3}: \mathrm{Ce}$ activated by $\mathrm{X}$-ray as a potent approach to produce large amounts of ROS applied in adjunctive tumor treatment. The $\mathrm{CaCO}_{3}$ :Ce particle was synthesized by the co-precipitation method and confirmed by crystalline phase identification in the vaterite phase. The cell viability and cytotoxicity of $\mathrm{CaCO}_{3}$ :Ce evaluated by WST-1 and LDH assays showed no intracellular cytotoxicity to normal cells compared to the control group. The cytotoxicity increased when $\mathrm{CaCO}_{3}: \mathrm{Ce}$ was activated by X-ray, and cell death was induced via necrosis or apoptosis in human lung adenocarcinoma A549 
cells. The result was consistent with ROS detection by the degradation of MB. The in vivo study also showed tumor growth inhibition based on the cell death mechanism induced by the overproduction of $\mathrm{ROS}$ and $\mathrm{CO}_{2}$. A safety assessment by blood/serum analysis and $\mathrm{H} \& \mathrm{E}$ examination indicated that $\mathrm{CaCO}_{3}$ :Ce is not toxic and causes no side effects to normal tissues. This study provides a novel therapeutic approach as an alternative tumor treatment.

Supplementary Materials: Supplementary materials can be found at http:/ /www.mdpi.com/1422-0067/20/5/ $1148 / \mathrm{s} 1$.

Author Contributions: F.-H.L. conceptualized and designed the experiments; W.-Y.W. performed the experiments; C.-C.Y. analyzed the data; F.-H.L. and C.-H.H. supervised experimental design; C.-C.Y. wrote the paper.

Acknowledgments: This work was financially supported by research funds collectively from BN-108-PP-01 (National Health Research Institutes of Taiwan). We also thank Su-Jen Ji and Chia-Ying Chien of National Taiwan University for their assistance in SEM and TEM experiments.

Conflicts of Interest: The authors declare no conflict of interest.

\section{References}

1. Choudhary, S.; Nouri, K.; Elsaie, M.L. Photodynamic therapy in dermatology: A review. Lasers Med. Sci. 2009, 24, 971-980. [CrossRef] [PubMed]

2. Robertson, C.A.; Evans, D.H.; Abrahamse, H. Photodynamic therapy (PDT): A short review on cellular mechanisms and cancer research applications for PDT. J. Photochem. Photobiol. B 2009, 96, 1-8. [CrossRef] [PubMed]

3. Barra, F.; Roscetto, E.; Soriano, A.; Vollaro, A.; Postiglione, I.; Pierantoni, M.; Palumbo, G.; Catania, M. Photodynamic and Antibiotic Therapy in Combination to Fight Biofilms and Resistant Surface Bacterial Infections. Int. J. Mol. Sci. 2015, 16, 20417-20430. [CrossRef] [PubMed]

4. Clement, S.; Deng, W.; Camilleri, E.; Wilson, B.C.; Goldys, E.M. X-ray induced singlet oxygen generation by nanoparticle-photosensitizer conjugates for photodynamic therapy: Determination of singlet oxygen quantum yield. Sci. Rep. 2016, 6, 19954. [CrossRef] [PubMed]

5. Zhou, Z.; Song, J.; Nie, L.; Chen, X. Reactive oxygen species generating systems meeting challenges of photodynamic cancer therapy. Chem. Soc. Rev. 2016, 45, 6597-6626. [CrossRef] [PubMed]

6. Matés, J.M.; Sánchez-Jiménez, F.M. Role of reactive oxygen species in apoptosis: Implications for cancer therapy. Int. J. Biochem. Cell Biol. 2000, 32, 157-170. [CrossRef]

7. Wiedmer, D.; Sagstuen, E.; Welch, K.; Haugen, H.J.; Tiainen, H. Oxidative power of aqueous non-irradiated $\mathrm{TiO}_{2}-\mathrm{H}_{2} \mathrm{O}_{2}$ suspensions: Methylene blue degradation and the role of reactive oxygen species. Appl. Catal. B Environ. 2016, 198, 9-15. [CrossRef]

8. Agostinis, P.; Berg, K.; Cengel, K.A.; Foster, T.H.; Girotti, A.W.; Gollnick, S.O.; Hahn, S.M.; Hamblin, M.R.; Juzeniene, A.; Kessel, D.; et al. Photodynamic therapy of cancer: An update. CA Cancer J. Clin. 2011, 61, 250-281. [CrossRef] [PubMed]

9. Quirk, B.J.; Brandal, G.; Donlon, S.; Vera, J.C.; Mang, T.S.; Foy, A.B.; Lew, S.M.; Girotti, A.W.; Jogal, S.; LaViolette, P.S.; et al. Photodynamic therapy (PDT) for malignant brain tumors-Where do we stand? Photodiagnosis Photodyn. Ther. 2015, 12, 530-544. [CrossRef] [PubMed]

10. Wan, M.T.; Lin, J.Y. Current evidence and applications of photodynamic therapy in dermatology. Clin. Cosmet. Investig. Dermatol. 2014, 7, 145-163. [PubMed]

11. Klein, S.; Dell'Arciprete, M.L.; Wegmann, M.; Distel, L.V.; Neuhuber, W.; Gonzalez, M.C.; Kryschi, C. Oxidized silicon nanoparticles for radiosensitization of cancer and tissue cells. Biochem. Biophys. Res. Commun. 2013, 434, 217-222. [CrossRef] [PubMed]

12. Kaščáková, S.; Giuliani, A.; Lacerda, S.; Pallier, A.; Mercère, P.; Tóth, É.; Réfrégiers, M. X-ray-induced radiophotodynamic therapy (RPDT) using lanthanide micelles: Beyond depth limitations. Nano Res. 2015, 8, 2373-2379. [CrossRef]

13. Yu, H.; Liu, N.; Wang, H.; Shang, Q.; Jiang, P.; Zhang, Y. Different responses of tumor and normal cells to low-dose radiation. Contemp. Oncol. 2013, 17, 356-362. [CrossRef] [PubMed]

14. Hamada, N.; Fujimichi, Y. Classification of radiation effects for dose limitation purposes: History, current situation and future prospects. J. Radiat. Res. 2014, 55, 629-640. [CrossRef] [PubMed] 
15. Chen, H.; Wang, G.D.; Chuang, Y.J.; Zhen, Z.; Chen, X.; Biddinger, P.; Hao, Z.; Liu, F.; Shen, B.; Pan, Z.; et al. Nanoscintillator-mediated $X$-ray inducible photodynamic therapy for in vivo cancer treatment. Nano Lett. 2015, 15, 2249-2256. [CrossRef] [PubMed]

16. Zhou, B.; Liu, B.; Zou, H.; Song, Y.; Gong, L.; Huo, Q.; Xu, X.; Sheng, Y. Facile synthesis of cubic and spindle-shaped $\mathrm{CaCO}_{3}$ particles and their applications as red phosphor doped with $\mathrm{Eu}^{3+}$. Colloids Surf. A Physicochem. Eng. Asp. 2014, 447, 166-171. [CrossRef]

17. Svenskaya, Y.I.; Pavlov, A.M.; Gorin, D.A.; Gould, D.J.; Parakhonskiy, B.V.; Sukhorukov, G.B. Photodynamic therapy platform based on localized delivery of photosensitizer by vaterite submicron particles. Colloids Surf. $B$ Biointerfaces 2016, 146, 171-179. [CrossRef] [PubMed]

18. Dong, Q.; Li, J.; Cui, L.; Jian, H.; Wang, A.; Bai, S. Using porous $\mathrm{CaCO}_{3} /$ hyaluronic acid nanocages to accommodate hydrophobic photosensitizer in aqueous media for photodynamic therapy. Colloids Surf. A Physicochem. Eng. Asp. 2017, 516, 190-198. [CrossRef]

19. Ueno, Y.; Futagawa, H.; Takagi, Y.; Ueno, A.; Mizushima, Y. Drug-incorporating calcium carbonate nanoparticles for a new delivery system. J. Control. Release 2005, 103, 93-98. [CrossRef] [PubMed]

20. Li, F.B.; Li, X.Z.; Hou, M.F.; Cheah, K.W.; Choy, W.C.H. Enhanced photocatalytic activity of $\mathrm{Ce}^{3+}-\mathrm{TiO}_{2}$ for 2-mercaptobenzothiazole degradation in aqueous suspension for odour control. Appl. Catal. A Gen. 2005, 285, 181-189. [CrossRef]

21. Albuquerque, A.R.; Bruix, A.; Sambrano, J.R.; Illas, F. Theoretical Study of the Stoichiometric and Reduced Ce-Doped $\mathrm{TiO}_{2}$ Anatase (001) Surfaces. J. Phys. Chem. C 2015, 119, 4805-4816. [CrossRef]

22. Yang, C.-C.; Sun, Y.-J.; Chung, P.-H.; Chen, W.-Y.; Swieszkowski, W.; Tian, W.; Lin, F.-H. Development of Ce-doped $\mathrm{TiO}_{2}$ activated by X-ray irradiation for alternative cancer treatment. Ceram. Int. 2017, 43, 12675-12683. [CrossRef]

23. Abrahamse, H.; Hamblin, M.R. New photosensitizers for photodynamic therapy. Biochem. J. 2016, 473, 347-364. [CrossRef] [PubMed]

24. Mallidi, S.; Anbil, S.; Bulin, A.L.; Obaid, G.; Ichikawa, M.; Hasan, T. Beyond the Barriers of Light Penetration: Strategies, Perspectives and Possibilities for Photodynamic Therapy. Theranostics 2016, 6, 2458-2487. [CrossRef] [PubMed]

25. Nakayama, M.; Sasaki, R.; Ogino, C.; Tanaka, T.; Morita, K.; Umetsu, M.; Ohara, S.; Tan, Z.; Nishimura, Y.; Akasaka, H.; et al. Titanium peroxide nanoparticles enhanced cytotoxic effects of X-ray irradiation against pancreatic cancer model through reactive oxygen species generation in vitro and in vivo. Radiat. Oncol. 2016, 11, 91. [CrossRef] [PubMed]

26. Kou, L.; Sun, J.; Zhai, Y.; He, Z. The endocytosis and intracellular fate of nanomedicines: Implication for rational design. Asian J. Pharm. Sci. 2013, 8, 1-10. [CrossRef]

27. Shin, S.W.; Song, I.H.; Um, S.H. Role of Physicochemical Properties in Nanoparticle Toxicity. Nanomaterials 2015, 5, 1351-1365. [CrossRef] [PubMed]

28. Khan, I.; Saeed, K.; Khan, I. Nanoparticles: Properties, applications and toxicities. Arab. J. Chem. 2017. [CrossRef]

29. Azzam, E.I.; Jay-Gerin, J.-P.; Pain, D. Ionizing radiation-induced metabolic oxidative stress and prolonged cell injury. Cancer Lett. 2012, 327, 48-60. [CrossRef] [PubMed]

30. Reisz, J.A.; Bansal, N.; Qian, J.; Zhao, W.; Furdui, C.M. Effects of Ionizing Radiation on Biological Molecules-Mechanisms of Damage and Emerging Methods of Detection. Antioxid. Redox Signal. 2014, 21, 260-292. [CrossRef] [PubMed]

31. Townley, H.E.; Wakefield, G. Rare Earth Doped Titania Nanoparticles Upregulate Cellular Reactive Oxygen Species upon X-ray Irradiation. BioNanoScience 2014, 4, 307-315. [CrossRef]

32. Saggu, S.; Hung, H.-I.; Quiogue, G.; Lemasters, J.J.; Nieminen, A.-L. Lysosomal Signaling Enhances Mitochondria-Mediated Photodynamic Therapy in A431 Cancer Cells: Role of Iron. Photochem. Photobiol. 2012, 88, 461-468. [CrossRef] [PubMed]

33. Bhatti, J.S.; Bhatti, G.K.; Reddy, P.H. Mitochondrial dysfunction and oxidative stress in metabolic disorders-A step towards mitochondria based therapeutic strategies. Biochim. Biophys. Acta (Bba) Mol. Basis Dis. 2017, 1863, 1066-1077. [CrossRef] [PubMed]

34. Wu, W.; Luo, L.; Wang, Y.; Wu, Q.; Dai, H.-B.; Li, J.-S.; Durkan, C.; Wang, N.; Wang, G.-X. Endogenous $\mathrm{pH}$-responsive nanoparticles with programmable size changes for targeted tumor therapy and imaging applications. Theranostics 2018, 8, 3038-3058. [CrossRef] [PubMed] 
35. Chen, L.Q.; Pagel, M.D. Evaluating pH in the Extracellular Tumor Microenvironment Using CEST MRI and Other Imaging Methods. Adv. Radiol. 2015, 2015, 206405. [CrossRef] [PubMed]

36. Min, K.H.; Min, H.S.; Lee, H.J.; Park, D.J.; Yhee, J.Y.; Kim, K.; Kwon, I.C.; Jeong, S.Y.; Silvestre, O.F.; Chen, X.; et al. pH-Controlled Gas-Generating Mineralized Nanoparticles: A Theranostic Agent for Ultrasound Imaging and Therapy of Cancers. ACS Nano 2015, 9, 134-145. [CrossRef] [PubMed]

37. Takeda, D.; Hasegawa, T.; Ueha, T.; Imai, Y.; Sakakibara, A.; Minoda, M.; Kawamoto, T.; Minamikawa, T.; Shibuya, Y.; Akisue, T.; et al. Transcutaneous Carbon Dioxide Induces Mitochondrial Apoptosis and Suppresses Metastasis of Oral Squamous Cell Carcinoma In Vivo. PLoS ONE 2014, 9, e100530. [CrossRef] [PubMed]

38. Deryugina, E.I.; Quigley, J.P. Tumor Angiogenesis: MMP-Mediated Induction of Intravasation- and Metastasis-Sustaining Neovasculature. Matrix Biol. J. Int. Soc. Matrix Biol. 2015, 44-46, 94-112. [CrossRef] [PubMed]

39. Nguyen, G.T.; Green, E.R.; Mecsas, J. Neutrophils to the ROScue: Mechanisms of NADPH Oxidase Activation and Bacterial Resistance. Front. Cell. Infect. Microbiol. 2017, 7, 373. [CrossRef] [PubMed]

40. Cross, A.R.; Segal, A.W. The NADPH oxidase of professional phagocytes-Prototype of the NOX electron transport chain systems. Biochim. Biophys. Acta 2004, 1657, 1-22. [CrossRef] [PubMed]

41. Murphy, R.C.; Johnson, K.M. Cholesterol, Reactive Oxygen Species, and the Formation of Biologically Active Mediators. J. Biol. Chem. 2008, 283, 15521-15525. [CrossRef] [PubMed]

(C) 2019 by the authors. Licensee MDPI, Basel, Switzerland. This article is an open access article distributed under the terms and conditions of the Creative Commons Attribution (CC BY) license (http:/ / creativecommons.org/licenses/by/4.0/). 